Towards best practice for assessing the impacts of climate change on groundwater, Hydrogeology Journal 2012, Volume 20, Issue 1, pp1-4

\title{
Towards best practice for assessing the impacts of climate change on groundwater
}

\author{
Holman $\mathrm{P}^{1 \bowtie}$, Allen, $\mathrm{DM}^{2}$, Cuthbert $\mathrm{MO}^{3}$ and Goderniaux $\mathrm{P}^{4,5}$ \\ ${ }^{1}$ Cranfield Water Sciences Institute, Department of Environmental Science and Technology, Cranfield \\ University, UK \\ ${ }^{2}$ Department of Earth Sciences, Simon Fraser University, Canada \\ ${ }^{3}$ School of Geography, Earth and Environmental Sciences, University of Birmingham, UK \\ ${ }^{4}$ Geosciences Rennes, UMR 6118, Université de Rennes 1 - CNRS, Rennes, France \\ ${ }^{5}$ Hydrogéologie et Géologie de l'Environnement, Université de Liège, Belgium
}

Keywords: Downscaling, adaptation, climate change, uncertainty, numerical modeling

\section{Introduction}

Groundwater is vital to human well being, providing two billion people with drinking water (Morris et al. 2003), supporting\$210-\$230 billion of annual global output of irrigated agricultural produce (Shah et al. 2000), and controlling the flows of water through the world's biomes (Alley et al. 2002). Given this importance, it is all the more disappointing that the Fourth Report of the Intergovernmental Panel on Climate Change (IPCC) still reports that there "has been very little research on the impact of climate 
change on groundwater" and that "the few studies of climate impacts on groundwater for various aquifers show very site-specific results" (Kundzewicz et al. 2007).

To contribute to addressing these perceived shortcomings and to maximize future study value, methodological recommendations are provided here for hydrogeologists to consider in groundwaterrelated climate change impact and adaptation studies.

\section{Using climate model projections}

Due to their current limitations, whether climate models produce climate projections that are fit for adapting to or managing the future is a matter of debate (Beven 2011). Although other approaches have been suggested (analogue regions, empirical models, projections based on historical responses - e.g. Dickinson et al. 2004), projections from global and regional climate models (GCMs and RCMs) are the default tool for generating future climate projections for input to recharge and hydrogeological models. If this approach is taken, the following are recommended:

Use climate scenarios from multiple GCM or RCMs. Many groundwater impact studies still use outputs from a single GCM or RCM, despite the recognized importance of climate model uncertainty in hydrological studies. Recently, the need for the groundwater community to use outputs from a range of GCMs or RCMs has been reemphasized (Toews and Allen 2009a; Goderniaux et al. 2009; Allen et al. 2010; Crosbie et al. 2011). For example, Jackson et al. (2011) found that the simulated changes in annual potential recharge to a UK Chalk aquifer using $13 \mathrm{GCMs}$ ranged from $-26 \%$ to $+31 \%$ by the 2080 s, with ten GCMs leading to predicted decreases and three to increases.

Use multiple emissions scenarios. A second major uncertainty in future climate is the emissions of greenhouse gases, which are expressed through the use of emissions scenarios, such as the IPCC Special Report on Emissions Scenarios (SRES) (Nakicenovic and Swart 2000). As these are considered to be 
equally probable, groundwater impact studies should span the range of emissions scenarios (e.g. Rosenberg et al. 1999; Crosbie et al. 2010) to avoid overly certain and unduly pessimistic/optimistic results.

Consider the implications of the choice of downscaling method(s). GCM or RCM outputs of future climate are generally downscaled (Fowler et al. 2007) because the scales of climate and hydrological models are different and biases exist between simulated and observed climatic variables. The simplest downscaling method is the 'perturbation' or 'delta-change' method (e.g. Jackson et al. 2011), which implicitly assumes that the future climate is a perturbed version of the present, with weather that has the variability characteristics of the baseline weather but is slightly wetter/drier and warmer/cooler in each month. Many studies suggest however that the future variance within climate parameters will change, such that more complex downscaling techniques which allow the statistical distribution of climatic variables to be adjusted should be preferred (Goderniaux et al. 2009; Kilsby et al. 2007; Mitchell 2003; Salathé 2005). The use of more complex methods however imposes significant additional computational requirements and can contribute additional uncertainty (Stoll et al. 2011; Chen et al. 2011). Holman et al. (2009) suggest that they should be preferred in systems which may be sensitive to changes in the temporal sequencing and persistence of recharge droughts. Given the different assumptions underpinning downscaling techniques, the choice of technique(s) should be guided by the compatibility between these assumptions and the objectives of the project and to the sensitivity of the aquifer.

\section{Improved hydrogeological coupling}

In order to assess the impact of assumed future conditions (climate, landuse, demographics, adaptation feedbacks, etc.) on groundwater distribution and its quantity and quality, some kind of coupling 
between these forcings and the hydrogeology needs to be assumed. For example, this may be through empirical models which relate climatic factors to groundwater conditions (Bloomfield et al. 2003) or through the use of physically-based recharge models (e.g. Jyrkama and Sykes 2007; Scibek and Allen 2006; Toews and Allen 2009a) and groundwater flow models (e.g. Goderniaux et al. 2009; Nyenje and Batelaan 2009; Rozell and Wong 2010; Scibek et al. 2007; Toews and Allen 2009b; van Roosmalen et al. 2007). In this respect the recommendations are:

Properly consider hydrogeological model structural error and model uncertainty. All groundwater impact studies are influenced by the validity of their system representation and conceptualisation, so that particular attention must be devoted to properly identifying and representing water entering and leaving the groundwater system through recharge, river-aquifer interactions, pumping and boundaries. When different domains, such as surface and subsurface, are strongly interconnected with important feedbacks, using models integrating all systems should be considered. Model structural (conceptual) error, despite often being the main source of uncertainty in model predictions, is rarely considered (Refsgaard et al. 2006; Rojas et al. 2009). For example, it has been shown that different groundwater recharge models (e.g. soil moisture balance models, 1-D variably saturated flow models, and empirical rainfall-recharge relationships) may give similar long term historic recharge rates but may still respond very differently to changes in intensity of precipitation (Cuthbert and Tindimugaya 2010). When viable model structures cannot be invalidated, ensembles of climate projections should be coupled with ensembles of retained hydrogeological models to produce credible results.

Consider the indirect climate change-induced impacts on recharge. Climate change will affect recharge through indirect changes to evapotranspiration. For example, increased $\mathrm{CO}_{2}$ can lead to partial closure of stomatal apertures on plant leaves suppressing transpiration (Field et al. 1995) but also to increased leaf area (LAI) which may result in an increase in transpiration and evaporation. The effects of such 
mechanisms have been detected in continental scale water balances (Gedney et al. 2006) and may produce an effect on global mean runoff that is comparable to that of radiatively forced climate change (Betts et al. 2007). Increased temperatures may also lead to changes in the timing of crop (e.g. emergence, senescence) or vegetation (e.g. bud burst, leaf fall) development. This suggests that recharge models should incorporate plant response to both elevated temperature and atmospheric $\mathrm{CO}_{2}$ to enable the recharge significance of such physiological changes to be assessed (e.g. Rosenberg et al. 1999; Eckhardt and Ulbrich 2003; Green et al. 2007). Since this effect may be minimal under historic control periods in some parts of the world, this is an important illustration of where model structural uncertainty described above should be accounted for.

Evaluate across as wide as possible a range of groundwater levels and/or climate conditions. Calibration is very often neglected, but is crucial to provide credibility (Hill and Tiedeman, 2007). Simulated climate conditions often predict extremes (such as multi-year droughts) that are outside of the historical baseline climatology (Holman et al. 2009). It is important that impact models be calibrated across as wide a range of historic groundwater levels and/or climate conditions as possible to increase the possibility of model robustness for future conditions, even though it is acknowledged that this is an insufficient test (Beven 1989). Using different kinds of observations (groundwater levels, river flow rates etc.) allows a joint and better constrained calibration of groundwater levels, fluxes and water balance components, and decreases correlation between parameters (Ebel and Loague, 2006; Hill and Tiedeman, 2007). In climate impact studies, physically based models are often preferred to empirical models because they rely on physical parameters which can, in some cases, be measured directly, and may offer more reliability when future climate goes beyond the calibration range. Despite uncertainty analysis receiving increased attention (e.g. Refsgaard et al. 2007) it is still not standard practice in water resources modelling studies (Pappenberger and Beven 2006). The implications of uncertainty in input data and parameters should be quantified (e.g Refsgaard et al. 2007; Hill and Tiedeman, 2007) and 
compared to other sources, as Goderniaux et al. (2011) showed that it can be more important than that linked to climate models and downscaling.

\section{Take account of socio-economic considerations}

Just as it is unacceptable to consider that future climate will be identical to today's (Milly et al. 2007), it is also inappropriate to assume that societal, political and economic conditions will remain unchanged into the future. To focus on the direct (temperature and precipitation) impacts of climate change is to neglect the potentially important role of future policy, societal values and economic processes in shaping the landscape above aquifers (Holman 2006) and groundwater demand, including the feedback due to adaptation. The following are recommended:

Consider socio-economic change, in particular its effect on landuse change and water demand. Rural land use is a consequence of socio-economic elements which affect the relative profitability of crops, livestock or trees either directly (e.g. subsidies, prices) or indirectly (labour, input prices, etc.) (Audsley et al. 2008; Rounsevell et al. 2003). Whilst the direct impacts of climate on simulated recharge are generally most important, socio-economic factors do produce regional changes in recharge, which can locally be highly significant, especially where there are major land use changes (Holman 2006; van Roosmalen et al. 2009), or changes to the spatiotemporal distribution of groundwater abstraction. Future groundwater demand will also not solely be a function of climate. Irrigation demand will be affected by future crop areas, water pricing and abstraction licensing (Henriques et al. 2008; Zhou et al. 2010; Holman and Trawick 2011). Environment Agency (2001) suggested that future domestic water demand in the UK may change by between -28 and +33\% between 1997 and 2025 depending on the socio-economic assumptions. 
Consider the efficacy of adaptation responses. The representation of adaptation within modelling is a key uncertainty in understanding the likely impacts of climate change and other environmental changes (Adger et al. 2007). This arises as adaptations involve people, at local to national governmental levels (Holman and Trawick 2011), but it is commonly assumed that adaptation is immediate and effective. Groundwater adaptation studies need to consider: (1) the triggers or critical impacts which necessitate adaptation (i.e. the cause of adaptation); (2) the time-lags involved in a measure being implemented through policy and taken-up by users; (3) the extent to which a measure might be taken up (which is especially important for non-mandatory policy measures); and (4) the effectiveness of the measure in reducing impacts.

Consider adaptation within robust decision making paradigms. Given the many and significant spatiotemporal uncertainties in future impacts on groundwater discussed above, specifying adaptation responses which rely on a strong ability to predict future risks or to foresee the eventual outcomes of decisions is an inappropriate paradigm (Lempert and Collins 2007)- uncertain information is more useful than a wrong certainty (Blöschl \& Montanari, 2011). Instead, groundwater management responses should be considered within alternative frameworks, such as robust decision-making and adaptive planning (e.g. Gleeson et al. 2011; Holman and Trawick 2011) or precautionary cost-benefit (Beven, 2011).

\section{Concluding remarks}

Given the vital importance of groundwater to human wellbeing and ecosystems, improved understanding of groundwater system behaviour in uncertain futures is required (Green et al. 2011). Whilst it is recognised that many of the recommendations outlined in this essay have time and 
computational costs, their appropriate implementation within the scope of a given study will afford a fuller appreciation of assessment uncertainty and an improved representation of adaptation responses. Such an holistic view will afford exciting opportunities for hydrogeologists to work more closely with a range of other disciplines including climate modelers, socio-economists, agricultural modellers and soil scientists.

\section{References}

Adger WN, Agrawala S, Mirza MMQ et al (2007) Assessment of adaptation practices, options, constraints and capacity. In Parry ML et al. (eds). Climate Change 2007: Impacts, Adaptation and Vulnerability, WGII, FAR, IPCC. Camb. Univ. Press, pp 717-743

Allen DM, Cannon AJ, Toews MW et al (2010) Variability in simulated recharge using different GCMs. Water Resour Res 46: W0OF03

Alley WM, Healy RW, LaBaugh JW et al (2002) Flow and Storage in Groundwater Systems. Science 296: $1985-1990$

Audsley E, Pearn KR, Harrison PA et al (2008) The impact of future socio-economic and climate changes on agricultural land use and the wider environment in East Anglia and North West England using a metamodel system. Clim Change 90: 57-88

Betts RA, Boucher O, Collins M et al (2007) Projected increase in continental runoff due to plant response to increasing carbon dioxide. Nature 448: 1037-1042

Beven KJ (1989) Changing ideas in hydrology - The case of physically-based models. J Hydrol 105: 157172. 
Beven KJ (2011) I believe in climate change but how precautionary do we need to be in planning for the future? Hydrolog Process 25: 1517-1520..

Bloomfield JP, Gaus I, Wade SD (2003) A method for investigating the potential impacts of climate change scenarios on annual minimum groundwater levels. Wat Environ J 17: 86-91

Blöschl G, Montanari A (2010) Climate change impacts-throwing the dice?,Hydrol Process 24: 374-381.

Chen J, Brissette FP, Leconte R (2011) Uncertainty of downscaling method in quantifying the impact of climate change on hydrology. J Hydrol 401: 190-202

Crosbie RS, McCallum JL, Walker GR et al (2010) Modelling climate-change impacts on groundwater recharge in the Murray-Darling Basin, Australia. Hydrogeol J 18: 1639-1656

Crosbie RS, Dawes WR, Charles SP et al (2011) Differences in future recharge estimates due to GCMs, downscaling methods and hydrological models. Geophys Res Lett 38: L11406

Cuthbert MO. Tindimugaya C (2010) The importance of preferential flow in controlling groundwater recharge in tropical Africa and implications for modelling the impact of climate change on groundwater resources. J Water Clim Change 1: 234-245

Dickinson JE, Hanson RT, Ferre TPA et al (2004) Inferring time-varying recharge from inverse analysis of longterm water levels. Water Resour Res 40: W07403

Ebel BA, Loague K (2006) Physics-based hydrologic-response simulation: Seeing through the fog of equifinality. Hydrolog Process 20: 2887-2900

Eckhardt K, Ulbrich U (2003) Potential impacts of climate change on groundwater recharge and streamflow in a central European low mountain range. J Hydrol 236:244-252 
Environment Agency (2001) Water resources for the future: A strategy for England and Wales, Environment Agency, Bristol, UK

Field C, Jackson R, Mooney H (1995) Stomatal responses to increased CO2: implications from the plant to the global-scale. Plant Cell Environ. 18: 1214--1255

Fowler HJ, Blenkinsop S, Tebaldi C (2007) Linking climate change modelling to impacts studies: recent advances in downscaling techniques for hydrological modelling. Int J Climatol 27: 1547-1578.

Gedney N, Cox PM, Betts RA et al (2006) Detection of a direct carbon dioxide effect in continental river runoff records. Nature 439: 835-838

Gleeson T, Alley WM, Allen DM et al (2011) Towards sustainable groundwater use: setting long-term goals, backcasting and managing adaptively. Ground Water. doi: 10.1111/j.1745-6584.2011.00825.x

Goderniaux $\mathrm{P}$, Brouyère $\mathrm{S}$, Fowler $\mathrm{HJ}$ et al (2009) Large scale surface - subsurface hydrological model to assess climate change impacts on groundwater reserves. J Hydrol 373: 122-138.

Goderniaux P, Brouyere S, Orban P et al (2011) Uncertainty of climate change impact on groundwater resources considering various uncertainty sources. In: Abesser $\mathrm{C}$ et al. (eds) Conceptual and modelling studies of integrated groundwater, surface water and ecological systems. IAHS Publ. 345, Wallingford, UK.

Green TR, Taniguchi M, Kooi H et al (2011) Beneath the surface of global change: Impacts of climate change on groundwater. J Hydrol 405: 532-560.

Green TR, Bates BC, Charles SP et al (2007) Physically based simulation of potential effects of carbon dioxide altered climates on groundwater recharge. Vadose Zone J 6: 597-609. 
Henriques C, Holman IP, Audsley E et al (2008) An interactive multi-scale integrated assessment of future regional water availability for agricultural irrigation in East Anglia and North West England. Clim Change 90: 89-111

Hill MC, Tiedeman CR (2007) Effective groundwater model calibration: With analysis of data, sensitivities, predictions and uncertainty. John Wiley \& Sons, New Jersey, 455 pp.

Holman IP (2006) Climate change impacts on groundwater recharge- uncertainty, shortcomings and the way forward? Hydrogeol J 14: 637-647

Holman IP, Tascone D, Hess TM (2009) A comparison of stochastic and deterministic downscaling methods for modelling potential groundwater recharge under climate change in East Anglia UKimplications for groundwater resource management. Hydrogeol J 17: 1629-1641

Holman IP, Trawick P (2011) Developing adaptive capacity within groundwater abstraction management systems. J Environ Manage 92(6): 1542-1549

Jackson CR, Meister R, Prudhomme C (2011) Modelling the effects of climate change and its uncertainty on UK Chalk groundwater resources from an ensemble of global climate model projections. J Hydrol 399: $12-28$

Jyrkama MI, Sykes, JF (2007) The impact of climate change on spatially varying groundwater recharge in the grand river watershed (Ontario). J Hydrol 338: 237-250

Kilsby CG, Jones PD, Burton A et al (2007) A daily weather generator for use in climate change studies. Environ Modell Softw 22: 1705-1719

Kundzewicz ZW, Mata L, Arnell NW et al (2007) Freshwater resources and their management. In: Parry ML, Canziani OF, Palutikof JP et al (eds) Climate change 2007: Impacts, Adaptation and Vulnerability. 
Contribution of Working Group II to the Fourth Assessment Report of the Intergovernmental Panel on Climate Change. Cambridge University Press, Cambridge, UK

Lempert RJ, Collins MT (2007) Managing the Risk of Uncertain Threshold Response: Comparison of Robust, Optimum, and Precautionary Approaches. Risk Analysis 27: 1009-1026

Milly PCD, Betancourt J, Falkenmark M et al (2007) Stationarity is dead: whither water management? Science 319: 573-574

Mitchell TD (2003) Pattern Scaling: An Examination of the Accuracy of the Technique for Describing Future Climates. Climat Chang 60(3): 217-242

Morris BL, Lawrence ARL, Chilton PJC et al (2003) Groundwater and its Susceptibility to Degradation: A Global Assessment of the Problem and Options for Management. Early Warning and Assessment Report Series, RS. 03-3. United Nations Environment Programme, Nairobi, Kenya

Nakicenovic N, Swart R (eds.) 2000 Special Report on Emissions Scenarios. A Special report of Working Group III of the Intergovernmental Panel on Climate Change. Intergovernmental Panel on Climate Change, Cambridge University Press Cambridge.

Nyenje PM, Batelaan O (2009) Estimating the effects of climate change on groundwater recharge and baseflow in the upper Ssezibwa catchment, Uganda. Hydrolog Sci 54(4): 713-726

Pappenberger F, Beven KJ (2006) Ignorance is bliss: Or seven reasons not to use uncertainty analysis. Water Resour Res 42: W05302.

Refsgaard JC, van der Sluijs JP, Brown J et al (2006) A framework for dealing with uncertainty due to model structure error. Adv Wat Resour 29: 1586-1597 
Refsgaard JC, van der Sluijs JP, Hojberg AL et al (2007) Uncertainty in the environmental modelling process - A framework and guidance. Environ Model Softw 22: 1543-1556

Rojas R, Batelaan O, Feyen L et al (2009) Assessment of conceptual model uncertainty for the regional aquifer pampa del Tamarugal. Hydrol Earth Syst Sci Discussions 6: 5881-5935

Rosenberg NJ, Epstein DJ, Wang D et al (1999) Possible impact of global warming on the hydrology of the Ogallala aquifer region. Clim Change 42:677-692

Rounsevell MDA, Annetts JE, Audsley E et al (2003) Modelling the spatial distribution of agricultural land use at the regional scale. Agric, Ecosyst Environ 95: 465-479

Rozell DJ, Wong TF (2010) Effects of climate change on groundwater resources at Shelter Island, New York State, USA. Hydrogeol J, 18: 1657-1665

Salathé EP (2005) Downscaling simulations of future global climate with application to hydrologic modeling. Int. J. Clim. 25:419-436

Scibek J, Allen DM (2006) Modeled Impacts of Predicted Climate Change on Recharge and Groundwater Levels. Wat Resour Res, 42, W11405

Scibek J, Allen DM, Cannon A et al. (2007) Groundwater-Surface Water Interaction Under Scenarios of Climate Change Using a High-Resolution Transient Groundwater Model. J Hydrol 333: 165-181

Shah T, Burke J, Villholth K (2007) Groundwater: a global assessment of scale and significance. In: Water for Food, Water for Life: A Comprehensive Assessment of Water Management in Agriculture. Earthscan and Colombo: International Water Management Institute, London 
Stoll S, Hendricks Franssen HJ, Butts M et al (2011) Analysis of the impact of climate change on groundwater related hydrological fluxes: a multi-model approach including different downscaling methods. Hydrol Earth Syst Sci 15: 21-38

Toews MW, Allen DM (2009a) Evaluating different GCMs for predicting spatial recharge in an irrigated arid region. J Hydrol 374:265-281

Toews MW, Allen DM (2009b) Simulated Response of Groundwater to Predicted Recharge in a Semi-Arid Region Using A Scenario of Modelled Climate Change. Environ Res Letters 4: 035003

van Roosmalen L, Christensen BSB, Sonnenborg TO (2007) Regional differences in climate change impacts on groundwater and stream discharge in Denmark. Vadose Zone J 6: 554-571

Zhou Y, Zwahlen F, Wang Y et al (2010) Impact of climate change on irrigation requirements in terms of groundwater resources. Hydrogeol J 18: 1571-1582. 